\title{
VAŽNOST OBRAZOVANJA ZASNOVANOG NA KOMPETENCIJAMA I ŽIVOTNIM VJEŠTINAMA ZA RAZVOJ DRUŠTVA
}

\section{- Sažetak -}

Obrazovanje zasnovano na kompetencijama ima višestruk značaj. Sticanja takvih znanja i vještina posebno je važno u savremenom dobu kada se društveni razvoj, $i$ to u svim njegovim bitnim segmentima, sve više bazira na kompetentnim znanjima $i$ vještinama. Kroz njihovo razvijanje $i$ primjenjivanje pruža se mogućnost dosezanja ne samo društvenih nego $i$ osobnih potencijala koje, nerijetko, ne možemo ni da sagledamo upravo zbog nedostatka kompetentnih znanja i vještina. Nije slučajno unutar Evropske unije određeno čak osam ključnih kompetencija neophodnih kako za lični tako i za kvalitativni društveni razvoj, što je predmet opservacije i u ovom radu.

\section{Ključne riječi: obrazovanje, kompetencije, društveni razvoj.}

\section{Uvod}

Nesumnjiva je važnost obrazovanja u ljudskom društvu, kako za pojedinca tako i za društvo u cjelini. Obrazovanje zasnovano na kompetencijama omogućava dosezanje vlastitih potencijala, kao i potencijala društva u cjelini. Primjereno je društvu znanja i konceptu cjeloživotnog učenja koje je paradigma XXI vijeka, vijeka informatike, globalizacije, brzog razvoja nauke i tehnike, ali isto tako i vijeka nestajanja starih i nastajanja novih poslova $\mathrm{i}$ radnih mjesta, sve većih i bržih promjena kojima se trebamo prilagoditi.

1 Vesna Banović, magistar sociologije, završila master studij na Fakultetu političkih nauka u Sarajevu (Odsjek sociologija), odbranila master tezu 2013. godine, na temu „Uticaj obrazovanja zasnovanog na kompetencijama i životnim vještinama na razvoj društva". Radila je za više međunarodnih organizacija i agencija i projekata (EC, UNICEF, OSCE). 
Nefunkcionalna država Bosna i Hercegovina i njen aparat koji ne može da se nosi sa naraslim problemima još su više podstaknuti globalnom ekonomskom krizom i recesijom. Velika nezaposlenost, posebno mladih, koja prelazi $50 \%$ radno sposobnog stanovništva, ratom razorena zemlja sa unazađenom i devastiranom ekonomijom i privredom, promjena društvenog sistema, tegoban poslijeratni oporavak, pristupanje EU integracijama, kao i vrlo složena organizaciona struktura zemlje sa dva entiteta, Distriktom Brčko i deset kantona, koji otežavaju donošenje odluka i efikasno rukovođenje, otežavajući je kontekst u kome se obrazovanje u BiH nalazi. Također, ne bi se smjelo zaboraviti da je bosanskohercegovačko društvo multietničko, sa elementima povratka nekadašnjoj interkulturalnosti, niti da su globalizacija i cjeloživotno učenje okvir u kome se nalazimo. U ovako složenom okviru promatrati ulogu obrazovanja, i to onog zasnovanog na kompetencijama, pravi je izazov i višeslojan zadatak.

Šta je to što želimo, kao društvo i čemu težimo? Koje vrline njegujemo i kakve ljude pripremamo za život? Da li želimo da se prilagođavamo, održavamo status quo, ili želimo da prosperitetno kreiramo svoju stvarnost $\mathrm{i}$ budućnost? Mnogo je pitanja, a odgovori na njih zavise i od uređenja države i društveno-ekonomskog sistema kao dominantnog vrijednosnog orijentira. Reduciranje nejednakosti u drušvu, kreiranje šansi za prosperitetan razvoj, ili održavanje statusa quo u društvu, predstavljaju i obrazovni izazov. U tom smislu nam je potreban obrazovni sistem zasnovan na kompetencijama, znanjima i vještinama usklađenim sa zahtjevima vremena.

\section{Pojmovni kontekst}

Kad je riječ o kompetencijama i njihovom značaju u obrazovnoj djelatnosti, u pojmovnom kontekstu čini se važnim naglasiti sljedeće:

Ključne kompetencije su prenosivi multifunkcionalni sklop znanja, vještina i stavova koji su potrebni svim pojedincima za njihovu realizaciju i razvitak, uključivanje u društvo i zapošljavanje. Treba ih razviti do kraja obaveznog obrazovanja, jer predstavljaju temelj za dalje osposobljavanje kao dio cjeloživotnog učenja. Iz ovakve definicije vidljivo je da su ključne kompetencije prenosive i stoga primjenljive u mnogim situacijama i kontekstima. One su preduvjet za odgovarajuću ličnu uspješnost u životu, radu i daljem učenju. ${ }^{2}$

2 Agencija za predškolsko, osnovno i srednje obrazovanje Bosne i Hercegovine: Identifikacija ključnih kompetencija i životnih vještina, 2010., MDGF YERP (Program zapošljavanja i zadržavanja mladih), 2010. 
Evropski okvir ključnih kompetencija i cjeloživotnog učenja je identifikovao i definisao osam ključnih kompetencija neophodnih za lični razvoj, aktivno građanstvo, socijalnu inkluziju i zapošljivost u društvu znanja, a to su:

1. Komunikacija na maternjem jeziku. Uključuje znanje i upotrebu maternjeg jezika kao i sposobnost izražavanja i tumačenja misli, osjećaja i činjenica u usmenom i pisanom obliku u cijelom nizu društvenih i kulturnih okolnosti;

2. Komunikacija na stranimjezicima. Uključuje znanjei upotrebu stranog jezika kao i sposobnost razumijevanja, izražavanja i tumačenja misli, osjećaja i činjenica u usmenom i pisanom obliku u primjerenom nizu društvenih okolnosti na jezicima koji nisu maternji;

3. Matematičke kompetencije $i$ osnovne kompetencije $u$ nauci $i$ tehnologiji. Na osnovnom nivou uključuje sposobnost vršenja matematičkih operacija, a na naprednom sposobnost i spremnost korištenja matematičkih oblika mišljenja koji imaju univerzalnu primjenu;

4. Informatička kompetencija. Uključuje sigurno i kritičko korištenje informatičkih tehnologija na poslu, u slobodno vrijeme i u komunikaciji. Ova kompetencija je povezana sa logičkim i kritičkim razmišljanjem, s visoko razvijenim vještinama baratanja informacijama i razvijenim vještinama komuniciranja;

5. Učiti kako se uči. Predstavlja sklonost organiziranja sopstvenog učenja, učinkovitog upravljanja vremenom te rješavanja problema. Takođe obuhvata i primjenu novih znanja i vještina u različitim kontekstima;

6. Socijalne i građanske kompetencije. Obuhvataju skup kompetencija koje pojedincu omogućavaju aktivno sudjelovanje u građanskom životu društva;

7. Inicijativa i preduzetništvo. Ova kompetencija predstavlja sposobnost da se planiraju i izvode projekti, da se vlastite ideje pretvore u praksu, da se bude spreman na preuzimanje rizika koji nosi svaka samostalna preduzetnička aktivnost;

8. Kulturna svijest i izražavanje. Predstavlja prepoznavanje i poštovanje kreativnog izražavanja ideja i osjećaja preko čitavog niza medija: muzike, vizualne umjetnosti, plesa, literature te prepoznavanje i poštovanje estetike. 
Ovim kompetencijama pridružene su dvije za područje BiH s obzirom na njenu specifičnost i potrebe, a to su:

1. Kreativno-produktivne kompetencije,

2. Tjelesno- zdravstvene kompetencije. ${ }^{3}$

Od 10 predloženih, fokusiraćemo se na tri kompetencije izuzetno bitne za postkonfliktno bosanskohercegovačko društvo: socijalno-građanske, preduzetničke i učiti kako se uči. Pomenute tri kompetencije su odabrane zbog njihove aktuelnosti u bh. društvu.

Životne vještine su one koje pridonose ličnom rastu i razvoju, tj. ostvarenju punog potencijala svake osobe, kako bi ona bila spremna suočiti se sa svim izazovima koje nosi život. Pomoću životnih vještina pojedinac je u stanju da istražuje alternative, promišlja i pravi efikasne izbore pri rješavanju problema. Takođe je u stanju da ostvari kvalitetne interpersonalne odnose $i$ komunikaciju.

Svjetska zdravstvena organizacija (WHO) definira životne vještine kao sposobnost za prilagodljivo i pozitivno ponašanje, koje omogućava pojedincima da se efikasno suočavaju sa zahtjevima i izazovima svakodnevnog života.

Također, UNICEF, UNESCO, zajedno sa WHO, daju popis strategija i tehnika 10 životnih vještina, a to su:

- rješavanje problema,

- kritičko mišljenje,

- efektivne komunikacijske vještine,

- odlučivanje,

- kreativno mišljenje,

- vještine interpersonalnih odnosa,

- vještine izgradnje samosvjesnosti,

- empatija,

- upravljanje stresom i

- upravljanje emocijama. ${ }^{4}$

Nedostajuće vještine prepoznate kroz više recentnih istraživanja Svjetske banke su:

- komunikacijske vještine,

- sposobnost rješavanja problema,

- sposobnost nezavisnog rada,

3 Ibid.

4 Ibid. 
- kako iskoristiti znanje i socijalne vještine za funkcionisanje u XXI vijeku i za obavljanje posla.

Pored nabrojanih, u Bosni i Hercegovini nedostaju sljedeće vještine i kompetencije:

- znanje stranog jezika,

- informatičke kompetencije,

- preduzetničke kompetencije,

- vještine javnog nastupa, stvaranja i prezentacije vlastitih nezavisnih stavova.

Zanimljiv je i indikativan kontekst u kome je nastao koncept cjeloživotnog učenja. Veoma je značajan uticaj Evropske unije na razvoj cjeloživotnog učenja, a Evropska unija je u sebi sublimirala 2 pristupa:

- OECD-ov neoliberalni,

- UNESCO-ov humanistčki.

Humanistički pristup podrazumijeva obrazovanje za samoostvarenje i ima široke socijalne i kulturne ciljeve, te predstavlja socijaldemokratski pristup. S druge strane, neoliberalni pristup podrazumijeva instrumentalizaciju obrazovanja putem njegove uglavnom ekonomske uloge. Evropski pristup obrazovanju zasnovan na ekonomiji znanja i postizanju velike konkurentnosti (evropska ekonomija da postane najkonkurentnija na svijetu, Lisabonski sporazum iz 2000.), uvažava oba ova principa i u sebi inkorporira ekonomske i demokratske ciljeve. Međutim, njihova dominantnost je različita kroz etape, počevši od prvobitnog nastanka koncepta cjeloživotnog učenja sredinom 60-ih godina XX vijeka pa do današnjih dana. Može se reći da je jačanje kriza podupiralo ekonomski princip neoliberalnog kapitalizma, dok je u stabilnija vremena dolazio do izražaja onaj socijaldemokratski, zasnovan na univerzalnom znanju.

U svakom slučaju, cjeloživotno učenje kao vrlo rastegljiv i prilagodljiv pojam koristi se u različitim zemljama za različite svrhe, gdje dominiraju ekonomski ciljevi i konkurentnost, a razlozi ličnog razvoja i aktivnog građanstva, kao humanističko-građanski ciljevi, bivaju potisnuti. Pored aktivnog građanstva, tu je i socijalna kohezija te razvoj multietničkog društva kao vrlo koristan faktor u višenacionalnim društvima pri rješavanju problema sa kojima se ona susreću, te posebno u rješavanju konflikata u postkonfliktnim zajednicama. 


\section{Socijalno-građanske kompetencije}

Socijalno-građanske kompetencije uključuju lične, interpersonalne i interkulturalne kompetencije i pokrivaju čitav niz ponašanja koja omogućavaju osobi da na efikasan i konstruktivan način učestvuje u socijalnom okruženju, sa posebnim naglaskom na multikulturna i multietnička društva, te da rješava konflikte na miran i konstruktivan način. Građanska komponenta znanja još uključuju i poznavanje koncepata demokratije, pravde, jednakosti, građanskih prava i bazičnih dokumenata koji garantuju ljudska prava. Ovo uključuje i poznavanje istorijskih činjenica vezanih za demokratizaciju i ustroj Evropske unije i vlastite države. Razvoj ove kompetencije ima u osnovi izgradnju vrijedonosnog sistema koji uključuje brigu za drugog, razumijevanje drugog i vještine da se sarađuje i konstruktivno djeluje u društvu. ${ }^{5}$ Ova kompetencija se uglavnom stiče na predmetima demokratija, istorija i geografija. Na razvoju vještina i stavova se radi na većem broju predmeta i to uglavnom društvenohumanističke grupe i maternjeg jezika.

Razvoj i napredak svakog pojedinca značajno zavisi od mogućnosti njegova uključivanja u aktivnosti zajednice u kojoj se nalazi. Polaskom u školu, te prvim socijalnim uključivanjem, učenici usvajaju oblike ponašanja prihvatljive za grupu i stiču osnovna znanja, vještine i stavove interpersonalne komunikacije. Razvojem i sazrijevanjem pojedinca proširuje se i njegova društvena uključenost, koja nalaže i potrebu za usvajanjem osnovih znanja, vještina i stavova vezanih za građanske kompetencije.

Interpersonalna kompetencija se odnosi na skup usvojenih oblika ponašanja koji su potrebni pojedincu za lično uključivanje u aktivnosti zajednice i interakciju sa drugim članovima. Interpersonalna kompetencija je preduslov za odgovarajuću komunikaciju između jednog i drugog člana zajednice. Građanske kompetencije predstavljaju znanja, vještine i stavove koji su neophodni svakom pojedincu radi uspješnijeg uključivanja u građanski život društva u kojem se nalazi.

Usko vezano sa građanskim kompetencijama je i obrazovanje za demokratsko društvo i obrazovanje o ljudskim pravima. Vijeće Evrope je donijelo Povelju Vijeća Evrope o obrazovanju za demokratsko društvo i obrazovanju o ljudskim pravima koja je usvojena u obliku preporuke na Komitetu Ministara 2010. godine. „Obrazovanje za demokratsko društvo” označava obrazovanje, obuku, jačanje svijesti, informacije, prakse i aktivnosti koje imaju za cilj da pojedinci, putem sticanja znanja, vještina i shvatanja

5 Agencija za predškolsko, osnovno i srednje obrazovanje Bosne i Hercegovine: Analiza nastavne prakse, MDGF YERP (Program zapošljavanja i zadržavanja mladih), 2010. 
i razvoja stavova i ponašanja, budu osnaženi u upražnjavanju i branjenju svojih demokratskih prava i odgovornosti u društvu, da vrednuju raznolikost i igraju aktivnu ulogu u demokratskom životu, sa ciljem promicanja i zaštite demokratije i vladavine zakona. „Obrazovanje o ljudskim pravima” označava obrazovanje, obuku, jačanje svijesti, informacije, prakse i aktivnosti čiji je cilj da pojedinci, putem sticanja znanja, vještina i shvatanja, razvoja stavova i ponašanja, budu osnaženi u davanju doprinosa izgradnji i branjenju univerzalne kulture ljudskih prava u društvu, sa ciljem promicanja i zaštite ljudskih prava i osnovnih sloboda. ${ }^{6}$

Odgoj i obrazovanje za ljudska prava i demokratsko građanstvo sadržava u sebi mnoge oblasti, kao što su:

- Razvoj socijalnih vještina, a posebno komunikacije i nenasilnog rješavanja sukoba;

- Tolerancija i uvažavanje različitosti;

- Poznavanje ljudskih prava i njihove adekvatne zaštite, kao i odgovornosti svake osobe za njihovo poštovanje;

- Ljudska prava i rodna ravnopravnost;

- Odgovorno ponašanje;

- Razvoj kritičkog mišljenja;

- Razumijevanje društvenih procesa i političkih sistema;

- Aktivno građanstvo i demokratija;

- Razumijevanje pojma multietničnosti, multikulturalizma i interkulturalizma;

- Poznavanje mehanizama djelovanja organizacija civilnog društva te upoznavanje sa mogućnostima udruživanja;

- Volonterizam;

- Aktivizam mladih;

- Razvoj preduzetničkog duha;

- Drugo.

Kao što možemo da vidimo, građanske kompetencije se umnogom dotiču obrazovanja za ljudska prava i demokratsko građanstvo. Nemanje građanskih kompetencija onemogućava pojedinca da bude aktivan građanin i da utiče na razvoj društva. Kod obrazovanja za ljudska prava izuzetno važnu ulogu nosi poznavanje Univerzalne deklaracije o ljudskim pravima, usvojene posebnom rezolucijom 1948. na zasjedanju Generalne skupštine Ujedinjenih nacija kao odgovor na enormno stradanje i patnju ljudi u II svjetskom ratu. Nepoznavanje ljudskih prava kao takvih, a Deklaracija ih detaljno navodi, te

6 Povelja Vijeća Evrope o ljudskim pravima. 
njihove zaštite, vodi ka neznanju i nesenzibiliziranosti kod kršenja tih istih prava. Ovaj proces je obostran: ne znaju ih nekada ni oni koji ih krše, a ni oni kojima su prekršena. U postratnim tranzicijskim multietničkim društvima ovo je posebno važno.

Netolerancija i neuvažavanje različitosti dovodi između ostalog i u konačnici i do ratnih sukoba. U slučaju Bosne i Hercegovine ovo je posebno značajno, ratom razorenom društvu potrebno je ponovno razvijanje duha tolerancije i uvažavanja različitosti jer samo tako ono može opstati. Za Bosnu i Hercegovinu su izuzetno bitni multietničnost i interkulturalizam. Za razliku od interkulturalizma, multikulturalizam pdrazumijeva življenje više kultura jednih pored drugih. Oni traže toleranciju i demokratičnost, a posebno interkulturalizam koji podrazumijeva zajedničku kulturu koja prihvata različitosti koje u nju ulaze i stapaju se. Sve ovo pod pretpostavkom da se želi razvoj tog i takvog društva. U slučaju Bosne i Hercegovine na razvoj društva djeluje više, nekad vrlo suprotstavljenih sila i politika. Nerazvijanje građanskih kompetencija i nemanje obrazovanja za demokratsko građanstvo vice versa sprečava razvoj društva. Ono podrazumijeva pasivne građane kojima je puno lakše manipulisati sa ciljem ostvarivanja nečijih prvo ličnih, a zatim i kroz partije i institucije sistema etabliranih interesnih grupa.

Demokratizacija društva je pretpostavka za demokratizaciju obrazovanja, a s druge strane, obrazovanje je pretpostavka razvoja društva. S tim u vezi javlja se potreba za novim područjima obrazovanja, poput obrazovanja za demokratsko građanstvo, čiji je cilj da doprinese razvoju kritičkog mišljenja i građanske odgovornosti, te da podstakne na građansku participaciju i aktivizam. Građansko obrazovanje utiče i na razvoj socijalnog kapitala u smislu stvaranja konstruktivnih veza na privatnom i javnom nivou koje će uticati na samoostvarenje pojedinca, a preko pojedinaca i na razvoj društva. Ove veze se na institucionalnom nivou ostvaruju preko udruženja, političkih partija, sindikata. Oni stvaraju mreže među ljudima te društveno povjerenje, koji olakšavaju saradnju na svakom planu i dovode do „win-win situacija” i uzajamne koristi povezanih.

Obrazovanje je političko i demokratsko pitanje. Razvojem građanskih kompetencija razvija se socijalni kapital i aktivni građani, što je preduslov demokratizacije i političke participacije aktivnih i odgovornih građana, a ta participacija odgovornih i aktivnih građana je uslov razvoja uravnoteženog društva. Demokratizacija društva podrazumijeva demokratizaciju njegovih članova te $\mathrm{u}$ tom smislu građanske kompetencije doprinose poštovanju drugačijeg mišljenja, utiču na vještinu debate i debatovanja, utiču na 
uočavanje i rješavanje društvenih problema te na moralnu odgovornost i političku kulturu. Sve nabrojano je uslov političkog, ekonomskog i, u konačnici, društvenog razvoja.

\section{Preduzetničke kompetencije}

Preduzetničke kompetencije podrazumijevaju sposobnost planiranja i izvođenja projekata, provođenje ideja u praksu te spremnost na preuzimanje rizika koji nosi svaka samostalna preduzetnička aktivnost. Kod ovih kompetencija je izuzetno važan element stava jer smo svjedoci da velik broj mladih, ali i onih starijih, posjeduju stručne kompetencije i sjajne ideje, ali iz straha od preuzimanja rizika i nespremnosti na samostalan rad ne usuđuju se pokrenuti vlastiti projekat ili preduzeće. Pozitivan stav upravo i uključuje proaktivnost, nezavisnost, motivaciju i spremnost na preuzimanje rizika bez straha od poraza. Razvoj ovih kompetencija se tradicionalno veže za stručne predmete, mada se očekuje da se samoinicijativa razvija unutar svih predmeta u redovnom školovanju.

Stoga se valja zapitati kako se razvijaju komponente samoinicijative i preduzetničkih kompetencija u pojedinim obrazovnim programima i u kojim predmetima. Analiza razlika u razvoju samoinicijative i poduzetničkih kompetencija između obrazovnih nivoa pokazuje vrlo interesantan rezultat. Osnovne škole nešto više rade na razvoju ove kompetencije nego gimnazije. Konkretno, u osnovnim školama se više radi na razvoju vještina timskog rada, razvijanju spremnosti na preuzimanje rizika i inicijative nego u gimnazijama.

U osnovnim školama, predmet koji dominantno razvija samoinicijativnost je demokratija; u njemu učenici rješavaju probleme u timovima i bivaju poticani na javno izražavanje mišljenja i debate sa svojim kolegama/kolegicama. U osnovnim školama su značajni predmeti za razvoj samoinicijativnosti i prirodoslovni predmeti, u kojima se više radi na razvoju vještina i stava, a ne toliko na usvajanju znanja (očekivano). U gimnazijama, demokratija je predmet na kojem nastavnici najviše insistiraju na usvajanju znanja, dok nastavnici filozofije najviše rade na razvoju stava.

U stručnim školama, demokratija više nije toliko značajna osim za usvajanje znanja, dok se vještine i stavovi razvijaju u prirodoslovnoj i društvenohumanističkoj grupi predmeta. Treba istaknuti i rezultate nastavnika u maternjem i stranom jeziku, koji u svim obrazovnim programima rade na razvoju vještina i stavova. Ohrabrujuća je činjenica da se nastavnici skoro svih predmeta trude da rade na vještinama i stavovima, što je vidljivo na prosječnim vrijednostima po elementima u svim obrazovnim programima. 
Možemo zaključiti da nastavnici većine predmeta različitim oblicima rada (timski rad, projekti) potiču razvoj vještina i stavova vezanih za samoinicijativu i poduzetničke kompetencije, a predmet na kojem učenici svih obrazovnih programa stiču najviše znanja je demokratija. ${ }^{7}$

Što se tiče razvijanja kompetencija kroz neformalno obrazovanje, situacija je drugačija i vrlo šarolika te bazirana uglavnom na projektima stranih agencija ili nevladinih organizacija (NVO). Više se projekata na području BiH bavilo ili se bavi razvijanjem poduzetničkih kompetencija kod srednjoškolske populacije učenika i oni su vrlo često takmičarskog karaktera. Školski timovi sastavljeni od najčešće desetak učenika dobijaju ograničena, ali poticajna donatorska sredstva ili se za njih izbore, u zavisnosti od metodologije projektnog ciklusa. Timovi prate cijeli projektni ciklus ovih mini projekata, te tako na djelu razvijaju i uključuju više usvojenih znanja i vještina te razvijaju nove: matematičke kompetencije za izradu i praćenje provedbe budžeta, jezičko-komunikacijske kompetencije na maternjem i stranom jeziku, javni nastup i prezentaciju, komunikaciju sa različitim zainteresovanim grupama, preduzetničke kompetencije itd. Mladi ljudi na ovaj način bivaju u situaciji da razvijaju i svoje građanske kompetencije tako da prvo rade snimanje situacije u svojoj okolini i daju presjek najurgentnijih potreba, koje onda pretoče u projektni prijedlog. Zatim skupljaju sredstva, provode projekat i javno predstavljaju njegove rezultate. Dakle višestruka korist je prepoznata kroz ove neformalne metode uvođenja poduzetničkih kompetencija u srednje škole.

Postoje i projekti uvođenja preduzetničkih kompetencija kroz neformalno obrazovanje za učenike osnovnih škola. Finansiranje ovih projekata za osnovnoškolce je rjeđe i sa manje sredstava, ali je pokazalo značajne rezultete u razvoju preduzetničkih vještina kod ove populacije. Radi se o učenicima završna tri razreda osnovnih škola. Njihovi projektni rezultati su veoma inspirativni i indikativni pokazatelji uspješnosti ranog razvoja kopetencija vezanih za preduzetništvo. Ispitivanje njihovih nastavnika - vođa timova pokazalo je veliku podršku ovakvom radu; nastavnici su kao preporuke istakli potrebu kontinuiranog ulaganja u ovakav vid aktivnosti te njihovo integrisanje u školske kurikulume. Uvođenje preduzetničkog učenja kroz neformalno obrazovanje prepoznat je i preporučen način integracije i u praksi provjeren kroz više projekata.

Evropskaunijai VijećeEvropeusvojoj recentnoj studiji,Uticaj neformalnog

7 Agencija za predškolsko, osnovno i srednje obrazovanje Bosne i Hercegovine: Identifikacija ključnih kompetencija i životnih vještina, 2010., MDGF YERP (Program zapošljavanja i zadržavanja mladih), 2010. 
obrazovanja u omladinskim organizacijama na zapošljivost mladih ljudi" navodi prednosti neformalnog obrazovanja mladih. Komunikacija, timski rad, donošenje odluka, organizacione vještine i samouvjerenost samo su neke od preporučenih vještina koje se razvijaju kroz neformalno obrazovanje. One su najtraženije kod poslodavaca pa tako ova vrsta obrazovanja razvija kompetencije potrebne za lakšu zapošljivost i zapošljivost generalno. Tu su i liderstvo i inerkulturalnost. Participacija u omladinskim projektima razvija socijalni kapital mladih i povezuje ih sa tržištem rada premošćujući nedostatak formalnog iskustva. To dalje znači preporuku vlastima za ulaganje više političke volje i finansija u neformalno obrazovanje mladih kako bi što više njih imalo pristup i povećanu mogućnost zapošljavanja.

„Strategija učenja o poduzetništvu u obrazovnim sistemima u $\mathrm{BiH}$ za period 2012-2015" je donesena 2011.godine. Ona predviđa uvođenje učenja o poduzetništvu u postojeće predmete u okviru postojećeg nastavnog plana i programa. Ova strategija slijedi EU definiciju preduzetništva, koja glasi: „Preduzetništvo se odnosi na mogućnost pojedinca da ideju pretvori u djelo. Ono uključuje kreativnost, inovativnost i sposobnost preuzimanja rizika, kao i mogućnost da pojedinac planira i provede projekte kako bi postigao određene ciljeve. Ovaj koncept pomaže svima u svakodnevnom životu, kod kuće, kao i među društvom; čini zaposlenike svjesnijim konteksta svoga posla i sposobnijim da iskoriste prilike, te predstavlja podršku preduzetnicima u pokretanju društvenih ili komercijalnih aktivnosti,,.8

Posebna tema su žene i preduzetništvo. Poslijeratni period i promjena društvenog uređenja u Bosni i Hercegovini odrazili su se i na žene i na muškarce te, uz istodobni uticaj globalizacije i promjene u sigurnosti radnih mjesta te nezaposlenosti, uticali su na žensko samozapošljavanje i na žensko preduzetništvo. Sa dolaskom rata dolazi do promjena na polju zapošljavanja kako muškaraca tako i žena. Žene počinju da posvećuju svoje vrijeme, karijeru i energiju prihvatajući bilo kakve poslove i istovremeno preuzimajući ulogu hraniteljice porodice. Neke su se u tome odlično snašle, razvile svoje potencijale, pronašle načine za zaradu, povezale se sa tržištem. Neke od njih su posao našle u mnogobrojnim novoosnovanim NVO-ima. Neki od NVO-a su počeli implementirati različite razvojne projekte te su angažovali žene za izradu ručnih radova ili za rad u poljoprivredi, u plastenicima, sa stokom na mini farmama, kao kooperante za mljekare i slično, u zavisnosti od projektnog zadatka i cilja. A neke žene su same sebe i one oko sebe organizovale pa

8 Ministarstvo civilnih poslova $\mathrm{BiH}$ : Strategija učenja o poduzetništvu u obrazovnim sistemima u BiH za period 2012- 2015. 
su koristile poplavu stranih i domaćih organizacija kao način ostvarivanja prihoda, sticanja novih znanja i vještina, povezivanje sa bližom i daljom okolinom.

Nakon rata kreće i razvoj malih i srednjih preduzeća. Pojedine strane donatorske organizacije, vladine i nevladine, programi, projekti i institucije, nudili su start up kredite upravo za žensko preduzetništvo kao i posebne obuke za osnaživanje žena i ženskog preduzetništva. Razvoj malih biznisa zavisio je i zavisi još uvijek od mnogo faktora, ali ono što je nesporno jesu poticaji i mogućnosti, koji su se ukazali ženama. Oni su im nudili način preživljavanja i izlaska iz siromaštva. Za one koje su se „,snašle, , i nešto više od toga. Pitanje je da li bi se neke od ovih pomenutih žena preduzetnica ikada prije rata, u drugačijim životnim i društvenim uslovima, bavile ovakvim poslovima. Specifična potkategorija su žene u 40-im koje su se počele baviti preduzetničkim aktivnostima nakon što su im djeca odrasla, a one ostale sa viškom vremena i energije, a manjkom finansijskih sredstava. Preduzetničke kompetencije ove kategorije je potrebno jačati serijom treninga; one će uticati na samopoštovanje, organizovanost, timski rad, razmjenu iskustava i znanja. Potrebno je učenje o preduzetništvu učiniti dostupnim što većem broju žena te razvijati preduzetničke kompetencije. Potrebno je, a bazirano na preduzetničkom znanju, promovisati i finansirati žensko preduzetništvo te organizovati obuke žena za preduzetništvo.

\section{Učiti kako se uči}

Učiti kako se uči predstavlja sklonost i sposobnost organizovanja i uređivanja vlastitog učenja bilo pojedinačno ili u grupi. Sastoji se od sposobnosti da učinkovito upravljamo svojim vremenom, rješavamo probleme, stičemo, procesuiramo, ocjenjujemo i asimiliramo znanje te da novo znanje i vještine primjenjujemo u raznim kontekstima - kod kuće, na poslu i u obrazovanju. Generalno govoreći, učiti kako se uči snažno doprinosi mogućnosti da upravljamo vlastitom karijerom. ${ }^{9}$

Učiti kako se uči je vrlo složena (kroz)kurikularna kompetencija, ali i vrlo važna za koncept cjeloživotnog učenja. Ona uključuje upravljanje procesom učenja, upravljanje vremenom, istrajnost, koncentraciju, sposobnost rješavanja problema, sposobnost samoprocjene, primjenu znanja i vještina, pravljenje obrazovnih izbora, upravljanje karijerom. Dakle, vrlo je važna u situaciji stvaranja novih poslova, nestanka starih te primjene naučenog.

9 Institut za društvena istraživanja Zagreb i ETF: Ključne kompetencije „Učiti kako učiti” i „Poduzetništvo” u osnovnom školstvu Republike Hrvatske, Istraživački izvještaj. 
Princip cjeloživotnog učenja traži prilagodljivost i primjenu novih znanja te ličnog i profesionalnog usavršavanja kako bi se postigla fleksibilnost u pristupu tržištu rada. Iz svih tih razloga kompetencija učiti kako se uči postaje ključnom kompetencijom XXI vijeka. Pojedinci koji ne znaju šta i kako učiti te kako se karijerno usavršavati mogu koristiti usluge centara za karijerno usmjeravanje i profesionalnu orijentaciju. Ova kompetencija je sadržajno najviše zastupljena u predmetima maternji jezik i istorija, a najmanje u nastavi biologije, hemije i fizike. U kontekstu akademskih dostignuća, kompetencija učiti kako se uči postaje vrijednost sama po sebi, koja omogućava samostalan rast i razvoj pojedinaca kroz njihov život i rad.

Treba napomenuti da je ova kompetencija posebno vezana za period nakon zadnjeg rata. Prije prihvatanja koncepta cjeloživotnog učenja i promjena na tržištu rada, učenje je uglavnom bilo kanalisano školskim sistemom. Ovakav pristup bio je u skladu sa mentalnim sklopom ljudi koji su bili naviknuti da neko drugi za njih trasira put: škola, fakultet, stalno zaposlenje. Nije se poticalo usavršavanje niti različiti karijerni izbori i promjene karijera. Promjene su donijele i nove paradigme: učimo cijeli život i mijenjamo više poslova u toku našeg radnog vijeka. Šta konkretno preduzeti da bi se mladi ljudi pripremili za učenje za cijeli život? Potrebno je organizovati karijerna savjetovališta pri osnovnim i srednjim školama koja će davati ne samo smjernice u vezi izbora buduće karijere nego i savjete u vezi učenja. Također je potrebno razvijati kompetenciju učiti kako se uči kroz različite predmete s obzirom na specifičnosti svakog predmeta i svakog učenika te na taj način kod učenika poticati ljubav prema učenju i znanju.

\section{Zaključna razmatranja}

Bosna i Hercegovina je od srednje razvijene evropske države prije rata došla u red nerazvijenih zemalja sa visokom stopom nezaposlenosti, prema evropskim mjerilima. Obrazovanje je postalo važan element u smanjenju siromaštva. Obrazovanje i edukacija povećavaju socijalni kapital i društvene veze na način da povećavaju ljudsku sposobnost funkcionisanja u društvu i kao članova društva, a to opet povećava ekonomski rast i razvoj. Socijalni kapital, s druge strane, povratno poboljšava obrazovne ishode, povećava toleranciju te smanjuje stopu kriminala. Dakle, obrazovanje je ključno za razvoj jer ne samo da povećava potencijale pojedinaca nego i društva u cjelini - socijalni kapital.

Potrebno je razvijati kompetencije i vještine sa posebnim osvrtom na one nedostajuće u bosanskohercegovačkom društvu kako bi se društvo 
brže razvijalo. Kritičko mišljenje, sposobnost iznošenja sopstvenih stavova, interpersonalne i komunikacijske vještine te upravljanje stresom samo su neke od vještina kojima je potrebno ovladati sada za sadašnjost i budućnost. Osim formalnog obrazovanja kao mjesta gdje bi se vještine i kompetencije trebale razvijati, vrlo je pogodno i obrazovanje odraslih. Također, treba poticati karijerno savjetovanje kako bi se osobe od mladih dana usmjeravale i razvijale u onom pravcu koji omogućava ostvarenje njihovih potencijala.

\section{IMPORTANCE OF COMPETENCE - BASED AND LIFE SKILLS - BASED EDUCATION FOR THE DEVELOPMENT OF SOCIETY}

\section{- Abstract -}

Competence-based education is multiply important, especially in modern times when the development of society, in all its substantial segments, is more and more based on acquisition of knowledge and skills. Development and usage of competences provide opportunity to scoop not only societal but also personal potentials, which we are often not able to comprehend due to lack of crucial knowledge and skills. It was no coincidence that within EU eight key competences were identified as necessary for both personal and social development, which is the object of observation in this work.

Key words: education, competences, social development.

\section{Literatura}

- Agencija za predškolsko, osnovno i srednje obrazovanje Bosne i Hercegovine: Identifikacija ključnih kompetencija i životnih vještina, 2010., MDGF YERP (Program zapošljavanja i zadržavanja mladih).

- Institut za društvena istraživanja Zagreb i ETF: Ključne kompetencije „Učiti kako učiti” i „Poduzetništvo” u osnovnom školstvu Republike Hrvatske, Istraživački izvještaj.

- Ministarstvo civilnih poslova BiH: Strategija učenja o poduzetništvu u obrazovnim sistemima u BiH za period 2012- 2015.

- Povelja Vijeća Evrope o ljudskim pravima. 